\title{
Pozzolanic Mortars for Restoration of Sacred Tuff Masonry Structures
}

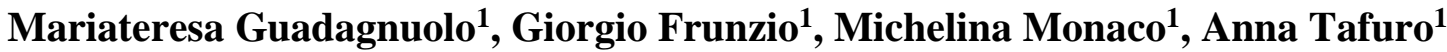 \\ ${ }^{I}$ Dipartimento di Architettura e Disegno Industriale, Università degli Studi della Campania "L. Vanvitelli", \\ Scuola Politecnica e delle Scienze di Base, Abbazia di San Lorenzo ad Septimum, 81031, Aversa, Italy
}

\section{Email:m.guadagnuolo@unicampania.it}

\begin{abstract}
Recent earthquakes have shown the seismic vulnerability of the Italian Architectural heritage and the need of interventions. The restoration design should take into account not only assessment and rehabilitation, but also the need of fruition of the cultural assets. These aspects have been considered in the last Italian seismic codes, a performance-based set of technical requirements to be addressed in the design process. In this framework, the requirements that the materials, meant to repair or replace historic ones, should fulfill are a key issue. In particular, for tuff masonry structures, the evaluation of the mechanical characteristics of the mortar is essential. Tests performed directly on samples withdrawn on site are perhaps the most reliable tools to determine the strength characteristics of a mortar to be used for restoration. Unfortunately, the possible dimensions of the samples are not compatible with the minimum required for a reliable mechanical test, so that the characterization of the old mortars and their historic context can be made obtaining information by the treatises of the time: components and their proportions, together with curing operations are often reported in the manuals. In particular, in the Middle Age the Roman knowledge about pozzolanic mortars was somewhat lost, and the results can be seen in the durability problems of several monuments of the period. These last considerations are the motivations of this paper, in which a study of the pozzolanic mortars in tuff masonry structures is provided. As a case study, the tuff masonry structures of the Paleocristian Basilica in Cimitile are considered and examined.
\end{abstract}

(C) 2019 The Authors. Published by IEREK press. This is an open access article under the CC BY license (https://creativecommons.org/licenses/by/4.0/).

\section{Keywords}

Lime mortar; restoration; experimental test; pozzolan

\section{Introduction}

The relationship between integration and conservation is one of the most important and recurring themes in the restoration debate. From the beginning of the 90s and in the last years, important studies are present in literature concerning the scientific knowledge of the materials that constitute the historical heritage (Rodrigues \& Henriques, 2004), (Stefanidou, Pachata, Konopissi, Karkadelidou \& Papayianni, 2014). Most of the Italian architectural heritage is located in seismic areas and after seismic scenarios a series of specific performance codes have been drawn up. The assessment of a heritage construction capacity before and after an intervention is needed (Bergamasco, Gesualdo, Iannuzzo \& Monaco, 2018) (Guadagnuolo \& Monaco, 2009). In particular, the evaluation of the mechanical properties of the materials to be used in the restoration project is fundamental in order to avoid physical-mechanical incompatibilities between mortar and masonry (Guadagnuolo, Faella, Donadio \& Ferri, 2014), (Papayianni \& Stefanidou, 2007). The studies of Baronio and Binda on ancient mortars are an exceptional contribution in the 
experimental field (Baronio \& Binda, 1997), but actually it is still difficult to create mortars similar to those used in the past with the same characteristics of deformability and resistance.

A few decades ago, the use of lime mortar was replaced by the general use of cement as a binder (Avelidis \& Moropoulou, 2004) and as a result, the experience of the building workers in the field was almost lost. The change in construction technology led the restorers to misuse cement mortars in architectural heritage. In the last two decades, lime mortars have regained their important role in the conservation of architectural heritage, although a broad background to understand the properties is needed. This paper enhances the knowledge of the most widespread mortars in the cultural heritage of Southern Italy. The Paleocristian complex in Cimitile is here considered as a case study, focusing attention on the problems related to the protection of the crests of the walls. The analysis starts from the indications in the architectural treatises and then presents a theoretical study on the mix proportions of pozzolanic lime mortar, supplemented by a wide range of experimental tests developed on three types of mortars obtained with different proportions, chosen for reproducing those used in the past. Specific procedures concerning the preparation of the mortars and the mechanical tests have been partly developed according to the Italian codes and partly specially designed. The test results are compared with a wide range of tests in the literature and a discussion on the variation of properties is provided. Conclusions should state concisely the most important propositions of the paper as well as the author's views of the practical implications of the results.

\section{Case study: Basilica nova in Paleocristian Cimitile Basilica}

The fulcrum of the Cimitile complex is the S. Felice's Basilica, whose original nucleus was built in the first half of the fourth century (Ebanista, 2006) on the tomb of the martyr. The basilica, described in the "Carmi" by Paolino (Nola, 1996), is certainly one of the first experiences of the invention of cult spaces for the Christian, a cult that takes place inside the building. After the collapse, the apse area and what remained part of a new cult building dedicated to S. Giovanni, while other parts emerged from the ground.

In 1931 with the fifteenth centenary of the death of Paolino, the superintendent Gino Chierici starts the restoration of S. Giovanni and after two years the excavation of the basilica nova (Carillo, 2004) begins. Nowadays there are few evidences of the basilica nova emerging in the void delimited by the Basilica of S. Felice, S. Maria degli Angeli's chapel and S. Giovanni's church (Figure 1. a).

The subject of this work is the problems related to the restoration using materials that meet the requirements of the codes. Evaluation of the mechanical properties of materials to be used for restoration projects should be known to correctly perform interventions. From what has been observed in situ and from the investigations conducted on samples of mortar (Megna, 2010) it has been noted that in particular the aggregate used for the mortars in the protection of the walls crests of the basilica nova is largely composed of brick shredder (cocciopesto) or tuff of varying granulometry, from 0 to $15 \mathrm{~mm}$ diameter, embedded in a mortar made by pozzolan and slaked lime. The protection of the crests of the walls is of paramount importance for the conservation of cultural heritage. The type of protection used is called "spalmata" of mortar (Binda, 2005) (Figure 1.b). The indications of this method are suggested by the Italian Charter of Restoration (Restauro, 1972) based on the intervention criteria tested since the 1920s. It is also important to specify that the protection of the ridges of the walls should never be considered definitive, but requires constant maintenance (Marino, 2009).
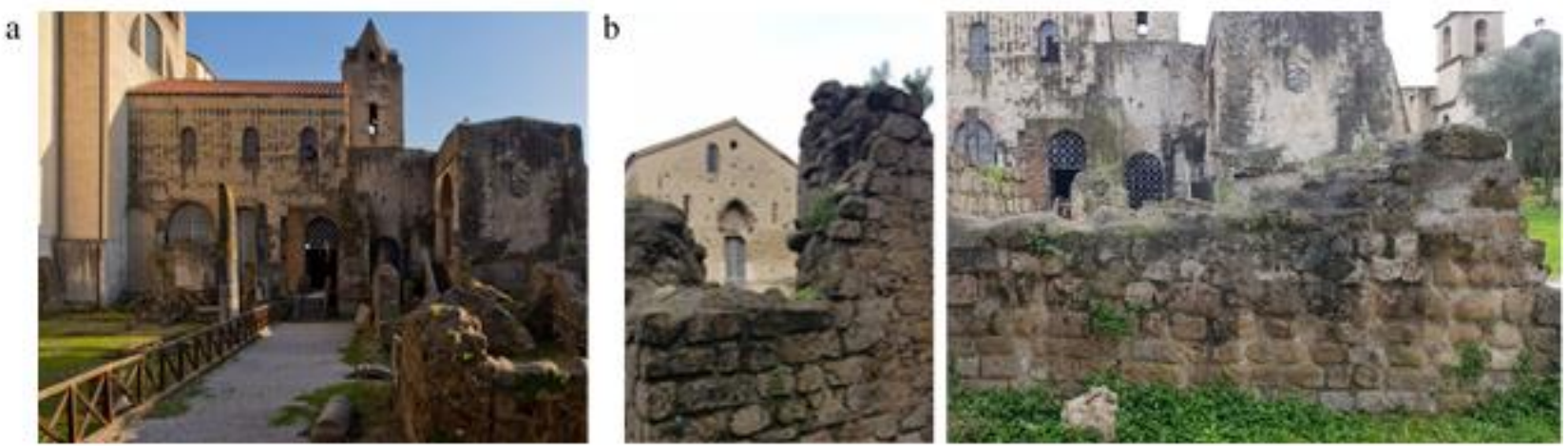

Figure 1. (a) Complex Paleocristian Cimitile:Basilica nova; (b) Details of protection of crests of walls with a tecnique called "spalmata" of mortar 


\section{Historical background}

The mortar has very ancient origins: the first binders deriving from calcination processes date back to the period of the terracotta and are plaster and air lime, generically called cements. Before the Romans, Egyptians, Greeks and Etruscans have extensively used the binders to compact the stones. The Romans, during the first century, have adopted the Vitruvius proportions obtaining durable structures over time through the use of pozzolana. In literature, after Vitruvius, Seneca and Plinius were among the first authors to attribute to the pozzolana the excellent resistance skills with the passage of time.

The Romans used hydraulic mortars containing a volcanic ash coming from the Gulf of Naples, precisely from Pozzuoli. In fact the material took the name of "pozzolana" from pulvis puteolanis. In case it was not easily available, the Romans also used cooked bricks or earthenware. The proportions used by Vitruvius are found in many Renaissance treatises (Blunt, 1962) and nineteenth-century (Ramazzoti \& Baccini, 1984). In the years the quality of lime certainly improved but never reached the levels of the Roman era.

\section{The role of mortar}

The evaluation of the masonry qualities depends on the determination of its mechanical and physical properties. The situ in tests have not always been able to provide the shear strength of the masonry, but some important values such as the Young's modulus, the transverse expansion and the compressive strength. In order to fully understand this extremely complex material it is necessary to gather information on the mechanical properties of a component that is widespread throughout Southern Italy: the mortar. For this reason an experimental campaign was conducted on mortars containing different types of lime and the traditional Neapolitan pozzolan:

- Mortar with industrial hydrated lime (Type A);

- Mortar with industrial lime putty (Type B);

— Mortar with laboratory lime putty, obtained slaking quicklime in laboratory(Type C).

In detail, Table 1 shows the composition of the three types of mortar. The water dosage in every set of tests was chosen to make the material workable in order to reproduce that of the building site.

Table 1. Ratios of Componentsfor Mortars

\begin{tabular}{|c|c|c|c|c|}
\hline Mortar type & Lime type & Lime & Pozzolan & Water \\
\hline $\mathrm{A}$ & $\begin{array}{c}\text { Industrial hydrated } \\
\text { lime }\end{array}$ & $1 \mathrm{~kg}$ & $3 \mathrm{~kg}$ \\
\hline $\mathrm{B}$ & $\begin{array}{c}\text { Industrial lime } \\
\text { putty }\end{array}$ & $1000 \mathrm{cc}$. & $1000 \mathrm{cc}$. & $1130 \mathrm{cc}$. \\
\hline $\mathrm{C}$ & $\begin{array}{c}\text { Laboratory lime } \\
\text { putty }\end{array}$ & $1000 \mathrm{cc}$. & $1000 \mathrm{cc}$. & $1060 \mathrm{cc}$. \\
\hline
\end{tabular}

Compressive tests were performed according to Italian standards of 1939 (RR. DD., 1939) or with RILEM recommendations (Van Balen, Papayianni, Van Hees, Binda \& Waldum, 2005). For each type of mortar cubes of 40x40x160mm were produced and water cured at 2860 and 180 days and finally subjected to increasing loads. 


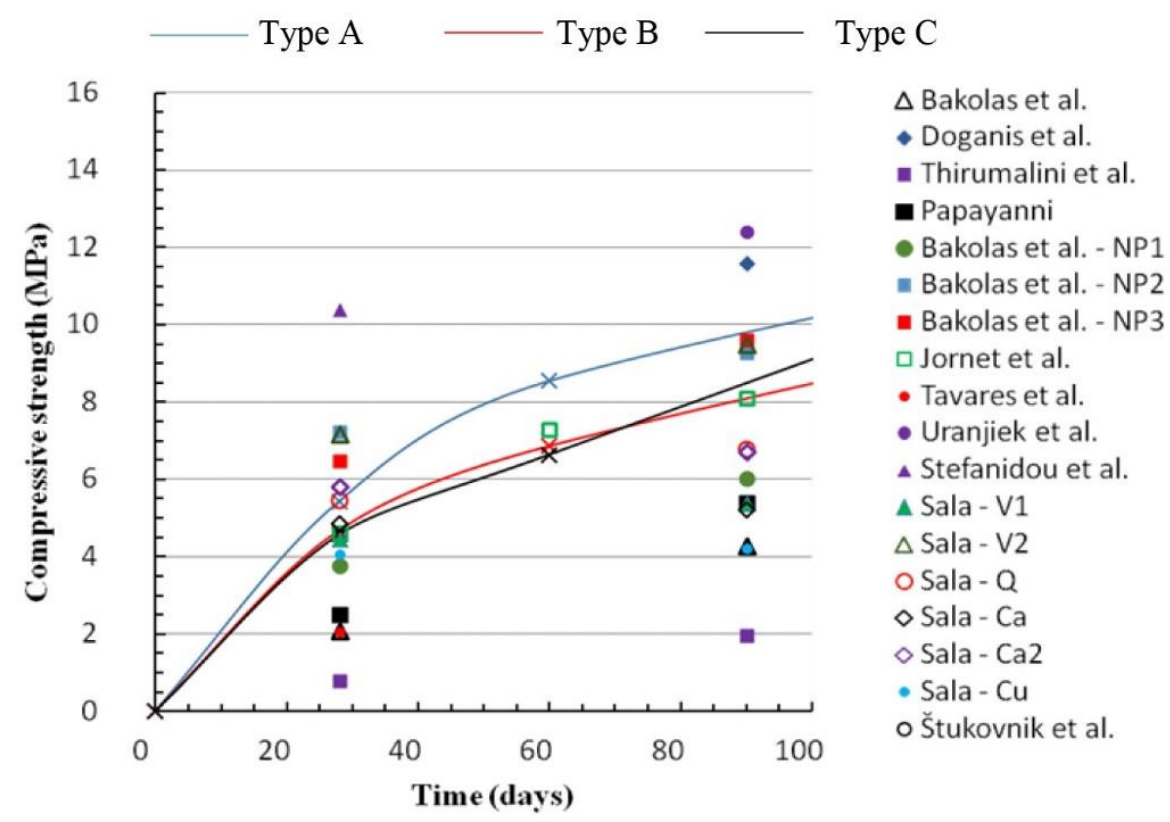

Figure 2. Compressive strength of $40 \times 40 \times 40 \mathrm{~mm}$ cubes versus curing time (Monaco, Aurilio, Tafuro $\&$ Guadagnuolo, 2019)

The results of the compressive tests on cubes are shown in Figure 2, comparing them with literature values. The tests result here reported are part of a larger experimental campaign, since more than 500 tests have been performed, with a very low value of the standard deviation. The increase in strength with the curing time is significant, as it can be easily deduced by observing the average variation in the reported compressive strength values. Mechanical characteristics are highly sensitive to the type of lime: mortars type B and type C, although the different dosage of water, present comparable strength values, worse than those of type A.

The results in literature variate from those here presented, due both to different mix proportions but also to curing method. In fact all the strength that are below the authors' data correspond to specimens made with artificial pozzolana and/or air curing conditions. On the contrary, the results in the upper part of the diagram correspond to air cured mortars.

\section{Conclusion}

In this paper the physical and mechanical characteristics of mortars used in the past for the construction of masonry buildings have been studied. In particular, the case under study is the set of walls crests in the Basilica nova in Cimitile (Naples, Italy). Over time the different restoration techniques have become increasingly invasive and not suitable for the conservation of cultural heritage. Tests performed directly on mortar samples, made according to the proportions of the treatises, could be a good reference for building practice. The present study was complied with other experimental studies, highlight the large variability of mortar strength based on curing conditions, mix proportion and quality of the aggregate, artificial or natural pozzolan. Surely, in order to be able to perform restoration actions on masonry buildings of particular historical and cultural interest, an accurate assessment of the mechanical and physical characteristics of the materials to be used in the conservation design is necessary.

\section{References}

Avdelidis, N. P. and Moropoulou, A. (2004). Applications of infrared thermography for the investigation of historic structures. Journal of Cultural Heritage. 5(1):119-127.

Balen, K. V., Papayianni, I., Hees, R. V., Binda, L., and Waldum, A. (2005). Introduction to requirements for and functions and properties of repair mortars. Materials and structure, 38(8):781-785,

Baronio, G. and Binda, L. (1997). Study of the pozzcolanicity of some bricks and clays, Construction and Building, volume 1.

Bergamasco, I., Gesualdo, A., Iannuzzo, A., and Monaco, M. (2018). An integrated approach to the conservation of the rooting structures in the Pompeian domus. Journal of Cultural Heritage, 31:141-151. 


\section{Guadagnuolo/ Proceedings of Science and Technology}

Binda, L. (2005). Dalla conoscenza e dalla caratterizzazione dei materiale e degli elementi dell'edilizia storica in muratura ai provvedimenti compatibili di consolidamento, . In Arti del workshop presso il Politecnico di Milano, pages 39-43, Milano, Milano. (in Italian).

Blunt, A. (1962). Artistic theory in Italy, 1450-1600. 50, Oxford University Press on Demand.

Carillo, S. (2004). L'epera di Gina Chierici nel complesse di Cimitile, in Fiengo G, Guerriere L, Monumenti e Ambienti. Protagonisti del restauro del dopoguerra. Italian, Napoli.

DD., R. (1939). "Norme per l'accetlazione e per il collaudo dei materiali da costruzione” 11/06/1939. in. Italian.

Ebanista, C. (2006). La tomba di S. Felice nel santuario di Cimitile a cinquant'anni dalla scoperta. Marigliano. (in italian).

Guadagnuolo, M., Faella, G., Donadio, A., and Ferri, L. (2014). Integrated evaluation of the Church of S.Nicola di Mira: Conservation versus safety. NDT \& E International, 68:53-65.

Guadagnuolo, M. and Monaco, M. (2009). Out of plane behaviour of unreinforced masonry walls, Protection of. Historical Buildings, 2:11771180 .

Marino, L. (2009). Materiali per un atlante delle patologie presenti nelle arce archeologiche $\varnothing$ negli edifici ridotti alla stato di rudere. pages 123 126, Firenze. (in Italian).

Megna, C. (2010). La protezione delle creste dei muri nella basilica nova di Cimitile. In Materia Cimitile, Atti della XX settimana della cultura scientifica e tecnologia del Miur, pages 61-68. (in Italian).

Monaco, M., Aurilio, M., Tafuro, A., and Guadagnuolo, M. (2019). Sustainable mortars for the application in the Cultural Heritage field. Journal of Building Engineering Editorial Board. (submitted).

Nola, P. (1996). i Carmi. vv I-II (in Italian).

Papayianni, I. and Stefanidou, M. (2007). Durability aspects of ancient mortars of the archaeological site of Olynthos. Journal of Cultural Heritage, 8:193-196.

Ramazzotti, L. and Baccini, R. (1984). L'edilizia e la regola: manuali nella Francia dell'Ouocento. (in Italian).

Restauro, C, (1972). Circolare Ministeriale . In n. 2/7 del 6 aprile 1972. (in Italian).

Rodrigues, P. F. and Henriques, F. M. A. (2004). Current Mortars in Conservation: An Overview. In International

Journal for Restoration, 10, pages 692-622.

Stefanidou. M., Pachta, V.. Konopissi, S., Karkadelidou, F., and Papayianni, I. (2014). Analysis and characterization of hydraulic mortars from ancient cisterns and baths. In Materials and structures, volume 47, pages 571-580, Greece.

\section{Acknowledgments}

The contribute of Ministry of Education, University and Research and particularly the Basic Research Activities Fund (FFABR) is gratefully acknowledged. 